\title{
RANCANG BANGUN PENGAMAN POWER SUPPLY BERBASIS ZERO CROSSING DETECTOR PADA LABORATORIUM KOMPUTER
}

\author{
Anak Agung Gde Ekayana ${ }^{1)}$, Anak Agung Ratna Rakasiwi 2) \\ ${ }_{1}$ Sistem Komputer, STMIK STIKOM Indonesia \\ email: gungekayana@stiki-indonesia.ac.id \\ 2 Teknik Informatika, STMIK STIKOM Indonesia \\ email: agung_ratna@yahoo.com
}

\begin{abstract}
Abstrak
Laboratorium merupakan salah satu sarana yang wajib ada dalam instansi pendidikan, adanya laboratorium menjadikan proses pembelajaran menjadi lebih optimal dan tentunya menghasilkan suatu produk inovasi dikemudian hari. Menurut Observasi yang telah dilakukan di Laboratorium STIKI Indonesia banyak ditemukan kendal kerusakan Power Supply pada komputer. Hal tersebut diakibatkan seringanya tegangan jala-jala PLN yang putus mendadak dan instalasi kelistrikan yang kurang tepat. Permasalahan tersebut tentunya harus dicarikan solusi untuk dapat meminimalisir kerusakan pada power supply, sehingga perangkat komputer dapat dipergunakan dengan optimal untuk pembelajaran.

Penelitian ini memberikan salah satu solusi untuk dapat mengatasi kendala tersebut, salah satu solusi yang diberikan berupa rangkaian pengaman power supply berbasis Zero Crossing Detector. Rancang bangun alat ini menggunakan beberapa komponen elektronika sebagai komponen penyusunnya yang dirangkaian sedemikian rupa. Alat ini digunakan atau disambungkan pada jala-jala PLN dan diteruskan pada power supply komputer.

Berdasarkan pengujian dari rangkaian Zero Crossing Detector yang dilakukan di Laboratorium. Hasil yang didapatkan,1)Rangkaian Zero Crossing detector dibangun menggunakan beberapa rangkaian elektronika yaitu, rangkaian filter, rangkaian penstabil, dan rangkaian pengaman. 2)Tegangan keluaran dari rangkaian Zero Crossing Detector menghasilkan tegangan sebesar 220 Volt dengan noise yang sudah diatur pada level rendah, pengurangan dan penstabil noise menggunakan rangkaian dioda, resistor dan kapasitor yang terdapat pada blok rangkaian Zero Crossing Detector. Pengukuran input dan output dilakukan untuk membandingkan hasil yang didapat sebelum melalui rangkaian dan sesudah melalui rangkaian. Selanjutnya output rangkaian disambungkan ke power supply dan dilakukan uji coba sebanyak 10 secara realtime, untuk menganalisis kerja dari rangkaian Zero Crossing Detector.
\end{abstract}

Kata kunci: Zero Crossing Detector, Power Supply, Elektronika

\begin{abstract}
Laboratory is one of the means that must exist in educational institutions, the laboratory makes the learning process becomes more optimal and certainly produce an innovation product in the future. According to observations that have been done in the laboratory STIKI Indonesia found a lot of damage to the Power Supply on the computer. This is caused by the frequent tension of the network of PLN suddenly dropped and the installation of electricity is less precise. The problem of course must be looked for solution to minimize damage to power supply, so computer device can be used optimally for learning.

This study provides one solution to overcome these obstacles, one of the solutions provided in the form of a power supply-based power supply circuit Zero Crossing Detector. The design of this tool uses several electronic components as its constituent components which are arranged in such a way. This tool is used or connected to the network of PLN and forwarded to the computer power supply.

Based on testing from the series of Zero Crossing Detector conducted in the Laboratory. Results obtained, 1) The Zero Crossing detector circuit is built using several electronic circuits, including: filter circuit, stabilizer circuit, and safety circuit. 2) The output voltage of the Zero Crossing Detector circuit produces a voltage of 220 Volts with noise set at a low level, noise reduction and stabilizer using a series of diodes, resistors and capacitors in the Zero Crossing Detector circuit block. Measurement of input and output is done to compare the results obtained before through the circuit and after going
\end{abstract}


through the circuit. Furthermore, the output of the circuit is connected to the power supply and tested 10 times in realtime, to analyze the work of the Zero Crossing Detector circuit.

\section{Keywords : Zero Crossing Detector, Power Supply, Electrical}

\section{PENDAHULUAN}

Kemajuan jaman saat ini, mendorong inovasi dan kreativitas semakin berkembang, disetiap lini kehidupan banyak dapat kita jumpai beranekaragam permasalahan, misalnya kemacetan, sarana prasana dll. Permasalahan yang timbul perlu kita carikan solusi, sehingga kedepannya dampak dari permasalahan tersebut tidak mengganggu kenyamanan masyarakat luas. Tidak sedikit kita menjumpai permasalahan dalam instansi pendidikan, salah satunya dalam hal sarana media belajar (komputer) mengalami kendala sehingga mengganggu kenyamanan proses belajar.

Laboratorium merupakan salah satu sarana yang wajib ada dalam instansi pendidikan, adanya laboratorium menjadikan proses pembelajaran menjadi lebih optimal dan tentunya menghasilkan suatu produk inovasi dikemudian hari. Kampus STIKI Indonesia mengharapkan semua perangkat pembelajaran dalam hal ini "komputer" yang ada di laboratorium dapat berfungsi sebagai mana mestinya. Semakin baik kondisi media pembelajaran tentunya akan berdampak positif pula untuk keberlangsungan proses belajar mengajar mahasiswa di laboratorium. LPIK STIKI Indonesia merupakan suatu lembaga di kampus STIKI yang memiliki beberapa prosedur, salah satunya adalah perawatan perangkat komputer di laboratorium.

Pada jabaran prosedur yang ada di LPIK, tentunya sudah menjalankan proses perawatan perangkat komputer yang ada di laboratorium, tetapi dalam kondisi di lapangan dimana dibantu oleh Asisten Laboratorium, sering menjumpai kurang optimalnya (rusak) perangkat komputer yang ada di Lab. Sejumlah komplain/catatan banyak diberikan oleh Aslab melalui buku "Kerja Nyata" yang ada di Sekretaris LPIK, terkait adanya kerusakan perangkat komputer yang ada di Lab. Komplain yang masuk selanjutnya dianalisis, untuk dapat mengetahui kerusakan-kerusakan apa saja yang sering muncul pada perangkat komputer di Lab. Ditinjau dari hasil analisis bidang infrastruktur LPIK terkait kerusakan yang ada, hasilnya sebagian besar kerusakan yang muncul adalah Komputer Mati.

Beberapa dugaan awal terkait kerusakan tersebut adalah sumber listrik yang tidak menyala/mati, setelah ditelusuri $\mathrm{MCB} /$ sumber listrik yang tersambung ke komputer berfungsi dengan baik, tetapi komputer masih tidak dapat menyala. Hipotesis yang muncul selanjutnya adalah adanya perubahan (naik turun) tegangan listrik dari jala-jalan PLN sehingga menyebabkan power supplay yang ada dikomputer mengalami short, sehingga beberapa komponen di box power supplay terbakar. (Data Observasi, 2017).

Permasalahan tesebut tentunya tidak dapat didiamkan begitu saja, salah satu penanganan yang sudah dilakukan yaitu menservices power supplay, jika dikaitkan dengan efisien waktu, penanganan tersebut membutuhkan waktu yang cukup lama sehingga tentunya menggangu proses belajar di Laboratorium. Beranjak dari permasalahan itu, perlu solusi yang dilakukan agar masalah tersebut dapat diselesaikan. Salah satu solusi yang bisa di optimalkan yaitu rancang bangun pengaman power supplay berbasis zero crossing detector pada komputer yang ada di laboratorium. Alat ini memiliki fungsi menstabilkan tegangan listrik yang berubah(naik turun) dari jalan-jalan PLN, sehingga input tegangan yang masuk ke power supplay menjadi stabil dan memperpanjang usia dari uni PS itu sendiri

Zero crossing detector merupakan rangkaian elektronika daya yang memiliki fungsi untuk mendeteksi titik persilangan nol disuatu sinyal AC baik sinusoidal maupun sinyal AC lainnya. Rangkaian tersebut sering digunakan untuk mengendalikan beban resistif, kapasitif maupun induktif pada tegangan $A C$ dan 
menggunakan eksekutor berupa triac. Titik persilangan dengan nol tegangan sumber untuk beban yang dikendalikan dengan komponen saklar berupa triac diperlukan untuk menentukan waktu mulai pemberian trigger atau sinyal kontrol pada triac tersebut.

Zero crossing detector merupakan rangkaian elektronis yang berfungsi untuk mendeteksi persilangan nol yang ada pada tegangan jala-jala. Rangkaian Zero Crossing Detector pada gambar dibawah akan memberikan output berupa pulsa sempit pada saat terjadi pesilangan nol pada tegangan AC yang di deteksi.

Rangkaian pembentuk dari zero crossing detector berupa komparator, differensiator dan schmitt trigger. Rangkaian Zero Crossing Detector ini diapalikasikan pada pemberian bias tegangan gate TRIAC. Rangkaian Zero Crossing Detector ini sering digunakan pada pernagkat pengontrolan heater $A C$ atau beban AC yang dikendalikan menggunakan TRIAC (Dasar, 2012)

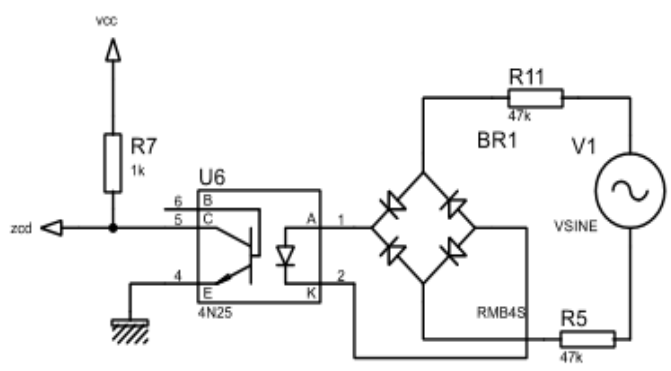

\section{Gambar 1. Rangkaian dasar Zero Crossing Detector}

Pemberian sinyal input pada triac yang tepat pada titik persilangan nol akan meningkatkan efektifitas dan efisiensi daya output dari pengendalian beban listrik dua arah (Erwanda, 2016).

Zero crossing detector adalah metode yang paling umum untuk mengukur frekuensi atau periode sinyal periodik. Hasil penelitian dari (Gupta, Thakur, \& Murarka, 2013) ini menyajikan studi komparatif berbagai teknik detektor persimpangan nol. Keakuratan pengukuran zero crossing untuk sinkronisasi kontrol sistem daya dan instrumentasi memerlukan pendekatan yang beragam untuk meminimalkan kesalahan deteksi fasa dari sinyal yang rusak dengan noise dan sinyal yang baik.

TRIAC (Tridiode Alternating Current Switch) yang mempunyai susunan yang terdiri dari 5 lapis bahan jenis $N$ dan $P$ termianal T1 dan T2 dapat mengalirkan dalam arah lain. Merupakan komponen eletronika daya yang digunakan sebagai pengatur arus rata - rata yang mengalir ke sumber beban yang dapat mengatur arus dalam dua arah AC (Kustija, 2014).

Sensor merupakan semua komponen elektronika yang digunakan mendeteksi besaran fisis menjadi besaran listrik seingga bisa dianalisa dengan rangkaian eletronika tertentu. Hampir semua perangkat elektronika sekarang terdapat sensor. Pada saat ini semakin ke depan, sensor ukuran volumenya semakin kecil dan ringkas. Kelebihannya memudahkan dalam aplikasinya, hemat ruang dan konsumsi daya. Sensor adalah bagian dari transduser (pengubah energi) yang gunanya untuk sensing. Adanya masukan energi luar masuk kebagian input dari transduser, sehingga perubahan kapasitas energi yang di terima dan dikirim ke bagian konverter dari transduser kemudian dirubah menjadi energi listrik (Dedy, 2001).

Optocoupler merupakan komponen eletronika yang memiliki 2 bagian penting yaitu transmitter dan reciever. Optocouler adalah komponen elekronika yang menggunakan cahaya infrared sebagai pemicu ON/OFF. Opto sendiri berarti Optic dan Coupler yang berarti pemicu bisa diartikan komponen yang bekerja berdasar pemicuan cahaya(AGUS, 2017).

\section{METODE}

Metode penelitian yang digunakan pada penelitian ini bersumber dari beberapa referensi, baik referensi jurnal nasional maupun jurnal internasional, dari beberapa referensi tersebut selanjutnya ditelaah dan dimodifikasi pada rancangan rangkaian Zero Crossing Detector yang paling sesuai dengan kebutuhan di lapangan (Lab Komputer). Pada metode 
yang dilakukan memiliki beberapa tahapan yang pertama adalah (1)menganalisa permasalahan yang ada di lapangan, (2) Perancangan alat, (3) Pembuatan alat, (4) Pengujian dan (5) Analisa Data. menjabarkan tahapan penelitian ini, antara lain :

\section{Mengidentifikasi Masalah dan Belajar Literatur}

Ini merupakan tahap awal memulai penelitian dimana penulis mengumpulkan berbagai litertur dan penunjangnya. Berbagai buku, jurnal, karya ilmiah maupun dari internet akan dijadikan sebagai pedoman melakukan sebuah penelitian. dan terlebih dahulu mengidentifikasi masalah tentang rancang bangun pengaman Zero Crossing Detector. Beberapa hasil penelitian menyebutkan bhawa dengan menggunakan rangkaian Zero Crossing Detector akan membuat tegangan yang tidak beraturan/banyak noise akan menjadi lebih stabil dan noise yang dihasilkan menjadi lebih rendah, dikarenakan pada rangkaian ZCD terdapat rangkaian filter untuk menghaluskan gelombang yang ada noisenya(Yeole et al., 2017).

Beberapa dugaan awal terkait kerusakan tersebut adalah sumber listrik yang tidak menyala/mati, setelah ditelusuri $\mathrm{MCB} /$ sumber listrik yang tersambung ke komputer berfungsi dengan baik, tetapi komputer masih tidak dapat menyala. Hipotesis yang muncul selanjutnya adalah adanya perubahan (naik turun) tegangan listrik dari jala-jalan PLN sehingga menyebabkan power supplay yang ada dikomputer mengalami short, sehingga beberapa komponen di box power supplay terbakar.

Beberapa literatur dari Hak Paten juga menyebutkan bahwa rangkaian Zero Crossing Detector sangat efektif untuk mendeteksi persimpangan dari tegangan sumber, dan terlebih lagi ada fitur Switching jika terjadi hubung singkat (Fields, Paul, City, Barrie, \& Ng, 1994)

\section{Perancangan Alat}

Tahap ini adalah perancangann dari identifikasi masalah dan studi literatur. Dalam garis besarnya meliputi perancangan hardware dari rangkaian zero crossing detector. Konsep pada rangkaian ini adalah menghasilkan tegangan AC 220 volt yang stabil untuk input power supply komputer. Berikut blok diagram alat.

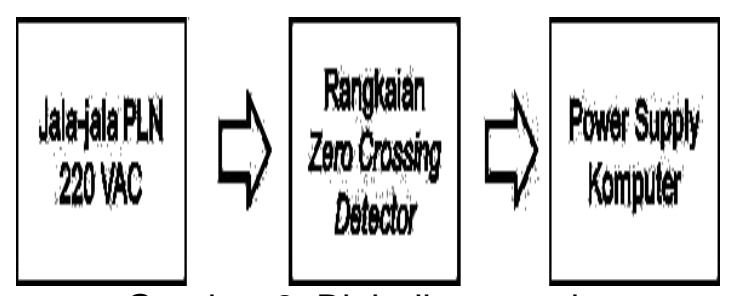

Gambar 2. Blok diagram alat

\section{Pembuatan Alat}

Pada tahap ini dimulai untuk merealisasikan alat yang akan dibuat, beberapa komponen elektronika diperlukan untuk dapat membangun rangkaian pengaman ini. Adapun alat dan bahan yang diperlukan, sebagai berikut:

\section{Alat dan Bahan}

1. Alat
1) Multimeter
2) Perkakas Tukang
3) Solder
4) Komputer
5) Obeng +-
6) Power Supply

2. Bahan
1) Resitor
2) Kapasitor
3) PCB
4) Optocopler
5) Integrated Circuit
6) Timah
7) Triac MOC
8) Kabel

\section{Pengujian Alat}

Pengujian alat bertujuan untuk mengetahui kinerja alat yang telah dikerjakan, dan mengoptimalkan kerja alat jika masih terdapat kendala/error pada rangkaian yang dibuat. Pengujian pada rangkaian ini adalah pengukuran tegangan yang keluar dari rangkaian zero crossing 
detector dan menggunakan power supply komputer sebagai beban.

\section{Analisa Data}

Mengambil dan menganalisa suatu data dari serangkaian pengujian yang dilakukan terhadap alat yang diuji. Mengambil data besaran dan satuan dari pengukuran mulai dari tegangan input dan keluaran alat, serta tegangan output dari power supply komputer. Proses analisa data menggunakan beberapa tools alat yaitu voltmeter AC, Osiloscope.

Flowchart Metode Penelitian diperlihatkan pada gambar dibawah ini.

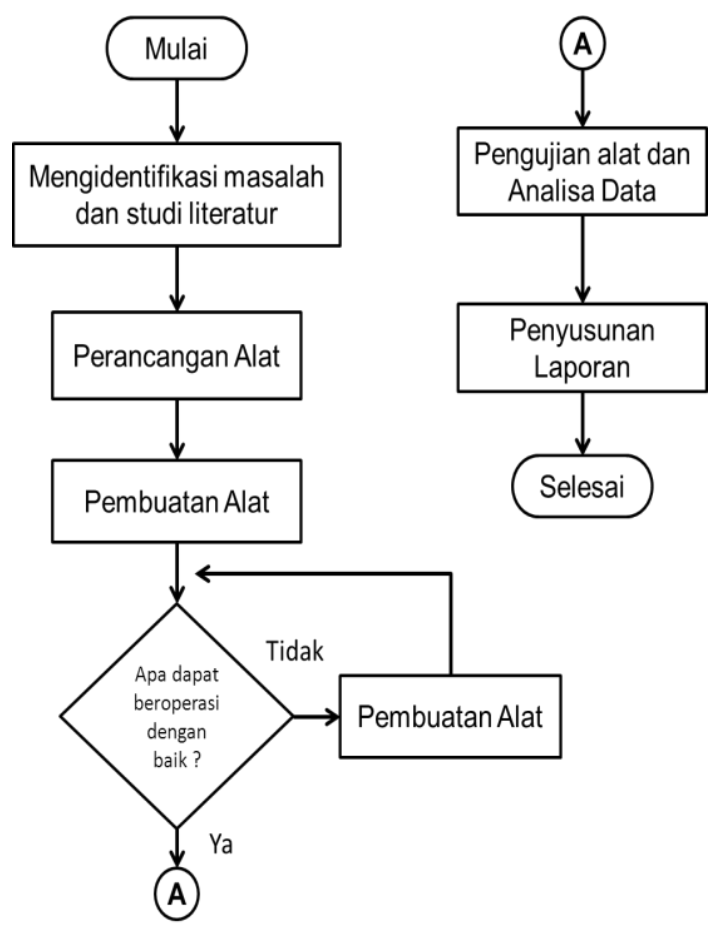

Gambar 3. Flowchart Metode Penelitian

\section{HASIL DAN PEMBAHASAN Desain Alat}

Alat yang dibuat dalam penelitian ini menggunakan kotak hitam berdimensi 15 $\mathrm{cm} \times 15 \mathrm{~cm}$, yang tingginya $8 \mathrm{~cm}$. desain tempat untuk penempatan komponen elektronika menggunakan bantuan aplikasi Corel Draw X3, bahan tempat alat yang dirancang terbuat dari bahan plastic isolasi yang tebalnya berukuran $3 \mathrm{~mm}$. Pada sisi kiri kotak diberikan jack untuk inputan ke jala-jala PLN, pada sisi kanan diberikan stop kontak untuk ke power supply.

\section{Perancangan Hardware}

Pada proses perancangan hardware memiliki beberapa tahapan yaitu: perancangan skematik rangkaian, perancangan layout $\mathrm{PCB}$, proses pencetakan $\mathrm{PCB}$, proses pelarutan PCB, proses pengeboran kaki-kaki komponen dan proses perakitan komponen pada papan PCB. Komponen yang digunakan pada perancangan hardware adalah perpaduan dari komponen aktif dan komponen aktif elektronika. Tools yang digunakan untuk menggambar skematik dan layout PCB adalah software Proteus. Proses pelarutan PCB menggunakan bahan kimia Ferichlorida.

Berikut alur dari perancangan Hardware dari rangkaian Zero Crossing Detector, ditampilkan pada gambar 3.

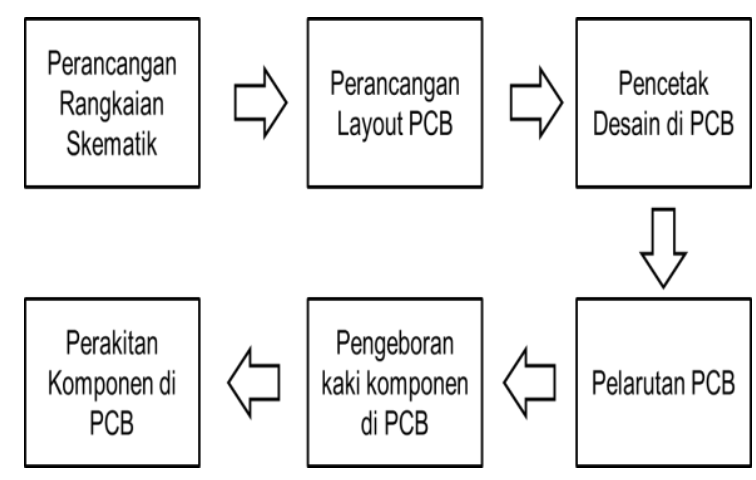

Gambar 4. Alur Perancangan Hardware

Pada rangkaian Zero Crossing Detector ini ada beberapa bagian antara lain, penyearah menggunakan diode IN 4007, rangkaian penstabil gelombang AC dengan menggunakan TRIAC dan rangkaian pengaman menggunakan Optocopler.

Rangkaian zero crossing berfungsi untuk mendeteksi saat tegangan VAC pada nilai nol volt. Titik ini merupakan acuan untuk menentukan nilai sudut penyalaan yang akan dibangkitkan. Contoh rangkaian zero crossing adalah Triac dan Optocopler. Saat fase positif komparator akan menghasilkan output high (Vcc) dan saat fase negative akan menghasilkan output low (0 volt) dengan output gelombang kotak dengan frekuensi sesuai dengan frekuensi ACnya yaitu 50 $\mathrm{Hz}$ 
Skema keseluruhan rangkaian Zero Crossing Detector ditunjukkan pada

gambar 5 berikut ini:

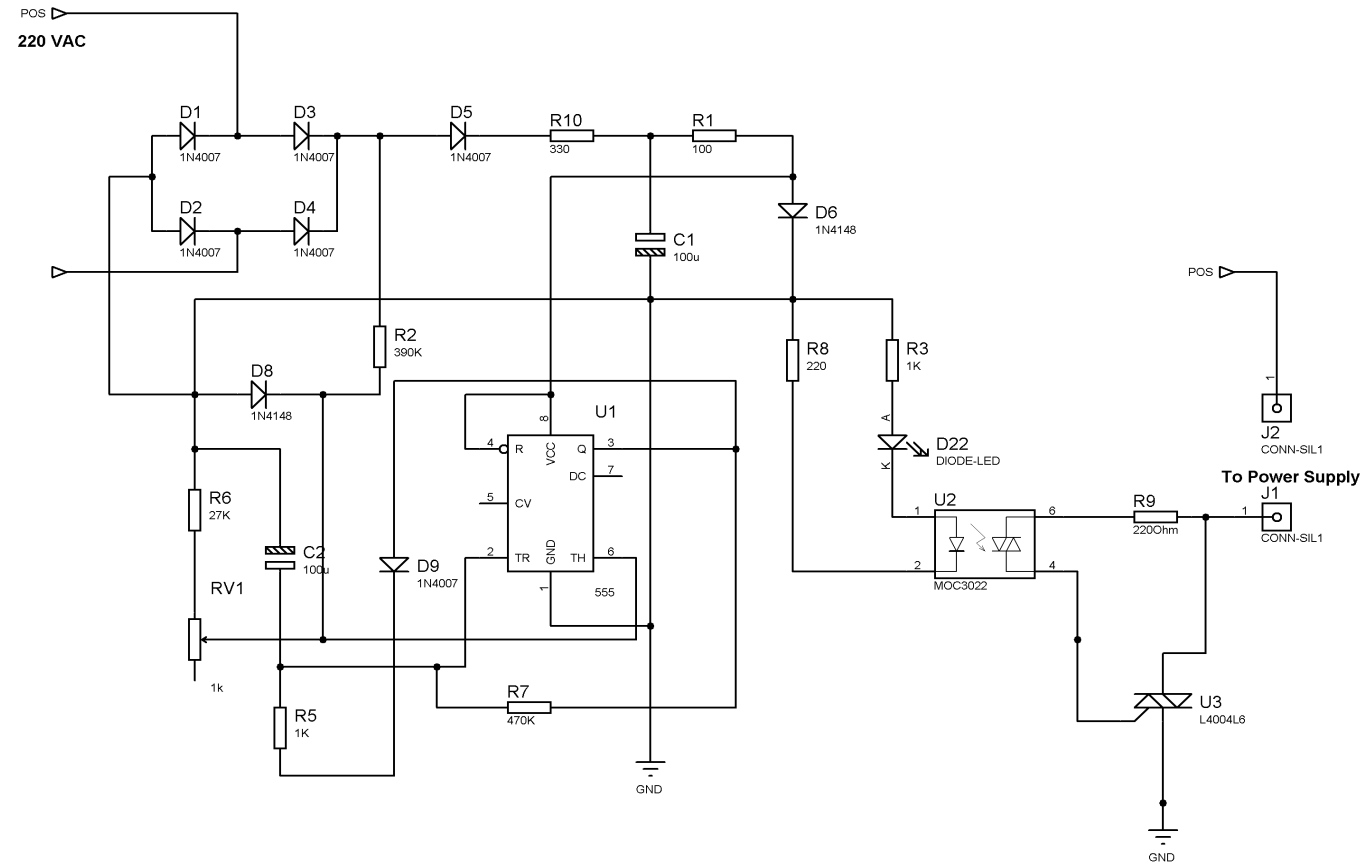

Gambar 5. Blok Skematik Rangkaian Zero Crossing Detector
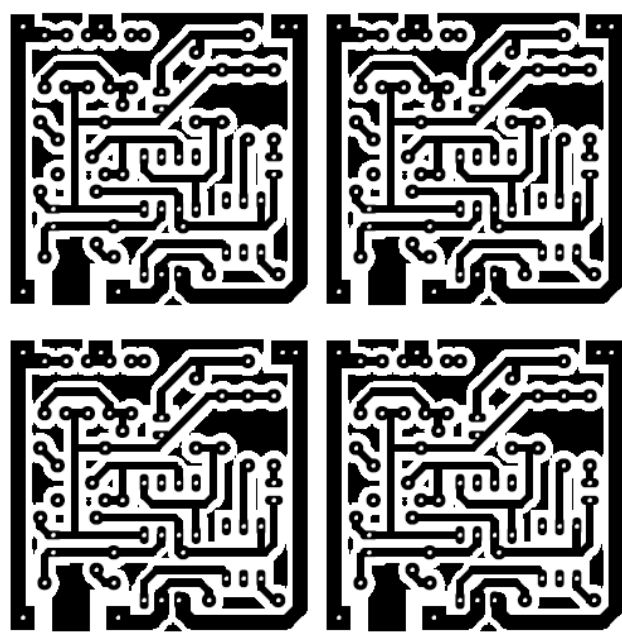

Gambar 6. Layout PCB Rangkaian Zero Crossing Detector
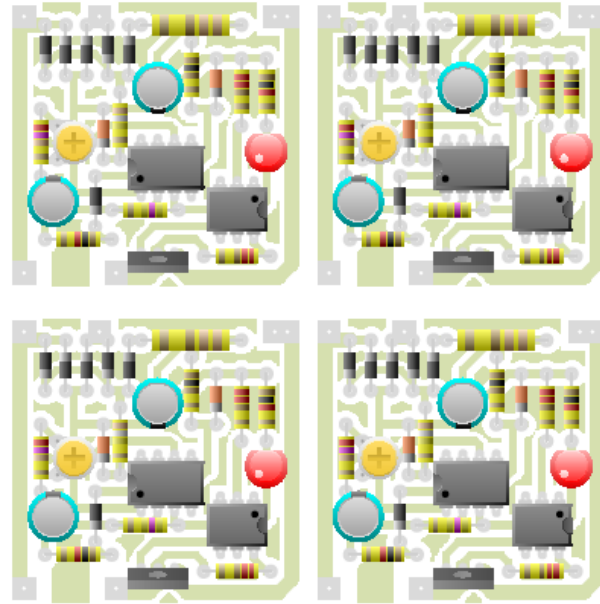

Gambar 7. Tata Letak Komponen

Rangkaian Zero Crossing Detector

Rangkaian Zero Crossing Detector merupakan rangkaian yang berfungsi memfilter frekuensi dan periode dari suatu sinyal periodik. Rangkaian ini saat diberikan sinyal AC (Alternating Current) selanjutnya akan dilakukan filter pada rangkaian dioda, dan selanjutnya ke rangkaian kapasitor.

Sinyal AC akan ditrigger ke rangkaian penstabil yaitu rangkaian Triac untuk meredam Noise/sinyal tak 
beraturan, sehingga akan mendapatkan sinyal lebih bersih dari sinyal sebelumnya. Rangkaian optocopler memiliki fungus sebagai rangkaian pengaman jika terjadi error pada rangkaian filter dan penstabil, sehingga pada tegangan yang menuju power supply akan menjadi lebih bersih dan aman.

Metode ini berfungsi untuk menentukan frekuensi suatu gelombang dengan cara mendeteksi banyaknya zero point pada suatu rentang waktu. Zero crossing detector berfungsi untuk mendeteksi perpotongan gelombang sinus pada tegangan $A C$ dengan zero point tegangan AC tersebut, sehingga dapat memberikan sinyal acuan saat dimulainya pemicuan sinyal PWM. Dengan menggunakan rangkaian zero crossing detector ini, kita dapat mendeteksi zero point sekaligus mengubah suatu sinyal sinusoidal (sine wave) menjadi sinyal kotak (square wave). Perpotongan titik nol yang terdeteksi adalah pada saat peralihan dari siklus positif menuju siklus negatif dan peralihan dari siklus negatif menuju siklus positif.

\section{Hasil Pengujian Alat.}

Pada tahap pengujian terlebih dahulu dilakukan pengukuran tegangan pada jala-jala PLN menggunakan alat ukur Multimeter. Hasil pengukuran mendapatkan hasil sebesar 220 Volt. Selanjutnya tegangan dari jala-jala PLN dihubungkan ke rangkaian Zero Crossing Detector untuk mengetahui kinerja dari alat yang dibuat.

Pengukuran selanjutnya dilakukan pada titik-titik tertentu pada rangkaian, yaitu pengukuran pada rangkaian filter diode, rangkaian filter kapasitor, rangkaian triac dan terakhir pengukuran tegangan pada out optocopler. Alat ukur Osiloscope digunakan untuk melakukan pengukuran terhadap sinyal berupa frekuensi, periode dan noise. Berikut ini hasil pengukuran yang telah dilakukan.

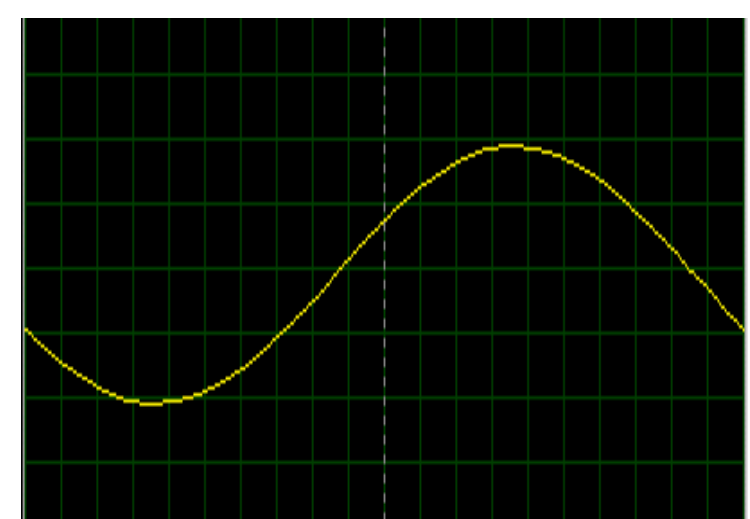

Gambar 8. Gelombang AC

Hasil pengukuran output rangkaian gelombang dengan Osiloscope menujukkan hasil seperti gambar 8 diatas.

Pengujian rangkaian zero crossing befungsi untuk mengetahui bentuk gelombang keluaran dari rangkaian. Untuk pengujian ini digunakan osciloscope.

Pemasangan osciloscope sesuai dengan yang dilihatkan oleh gambar berikut ini:

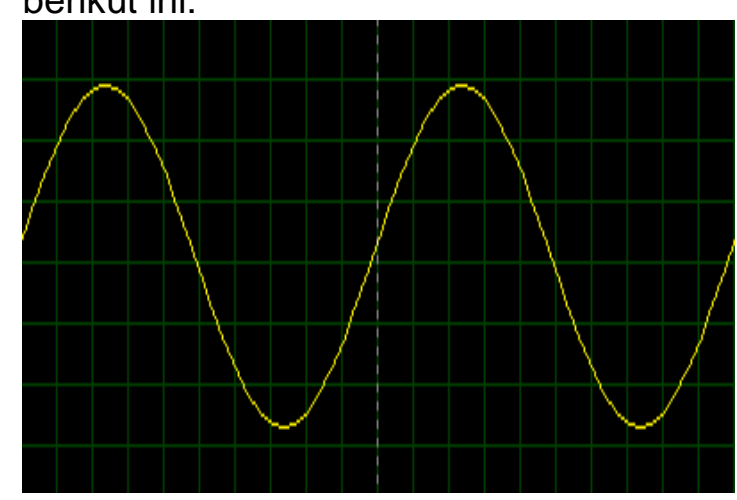

Gambar 9. Pengukuran Tegangan keluaran rangkaian

Pengukuran tegangan pada output rangkaian Zero Crossing Detector menunjukkan hasil sebesar 220 volt. Hasil output dari rangkaian Zero Crossing Detector saat dilakukan pengukuran menghasilkan tegangan yang sama dengan tegangan pada jala-jala PLN. Kelebihan output dari rangkaian ini adalah menghilangkan noise pada tegangan input, sehingga power supply mendapatkan tegangan yang bersih dan aman, harapannya untuk meminimalisir kerusakan power supply komputer.

Rangkaian zerro crossing detektor sering diaplikasikan pada peralatan yang digunakan untuk mengendalikan beban 
pada jaringan listrik $A C$ dan menggunkan eksekutor berupa TRIAC atau SCR. Titik persilangan dengan nol tegangan sumber untuk beban yang dikendalikan dengan komponen saklar berupa TRIAC atau SCR diperlukan untuk menentukan waktu mulai pemberian triger atau snyal kontrol pada SCR atau TRIAC tersebut.

Pemberian sinyal input pada SCR atau TRIACyang tepat pada titik persilangan nol akan meningkatkan efektifitas adan efisensi daya output dari pengendalian beban listrik AC. Semoga bermanfaat dan memberikan gambaran tentang teknik Zero Crossing Detektor dalam pembuatan peralatan elektronik yang memerlukan Zero Crossing Detektor.

Pengujian terhadap rangkaian Zero Crossing Detector dilakukan sebanyak 10 $x$ secara realtime. Pengukuran menggunakan alat ukut AVO meter yang dilakukan pada dua titik yaitu pada input dan pada output. Hasil pengujian dapat disajikan pada Tabel 1

Tabel 1. Hasil Pengujian Rangkaian

\begin{tabular}{cccc}
\hline No & Waktu & Input & Output \\
\hline 1 & 10 Menit & $220 \mathrm{VAC}$ & $220 \mathrm{VAC}$ \\
2 & $30 \mathrm{Menit}$ & $220 \mathrm{VAC}$ & $220 \mathrm{VAC}$ \\
3 & $50 \mathrm{Menit}$ & $220 \mathrm{VAC}$ & $220 \mathrm{VAC}$ \\
4 & $60 \mathrm{Menit}$ & $220 \mathrm{VAC}$ & $220 \mathrm{VAC}$ \\
5 & $120 \mathrm{Menit}$ & $220 \mathrm{VAC}$ & $220 \mathrm{VAC}$ \\
6 & 240 Menit & $220 \mathrm{VAC}$ & $220 \mathrm{VAC}$ \\
7 & 360 Menit & $220 \mathrm{VAC}$ & $220 \mathrm{VAC}$ \\
8 & 480 Menit & $220 \mathrm{VAC}$ & $220 \mathrm{VAC}$ \\
9 & 600 Menit & $220 \mathrm{VAC}$ & $220 \mathrm{VAC}$ \\
10 & 720 Menit & $220 \mathrm{VAC}$ & $220 \mathrm{VAC}$ \\
\hline
\end{tabular}

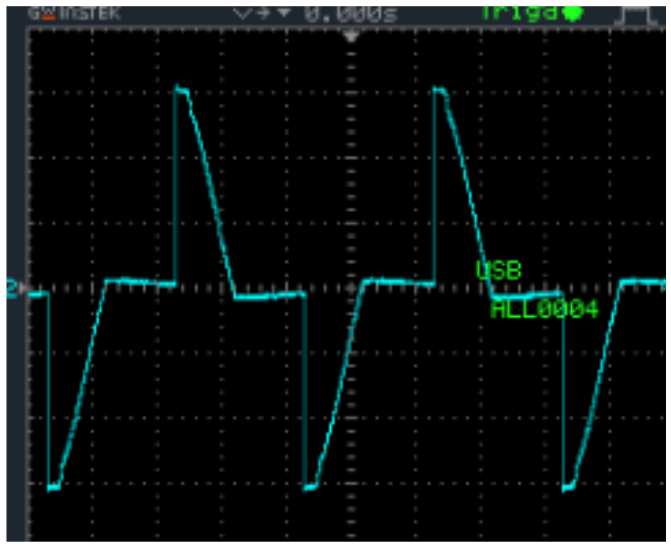

Gambar 10. Hasil Pengukuran Gelombang pada input Rangkaian Zero Crossing Detector

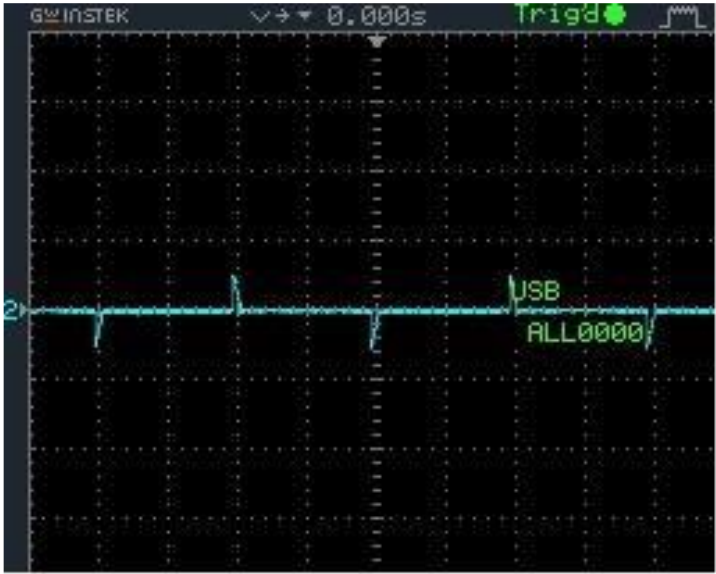

Gambar 11. Sinyal noise yang difilter Rangkaian Zero Crossing Detector 


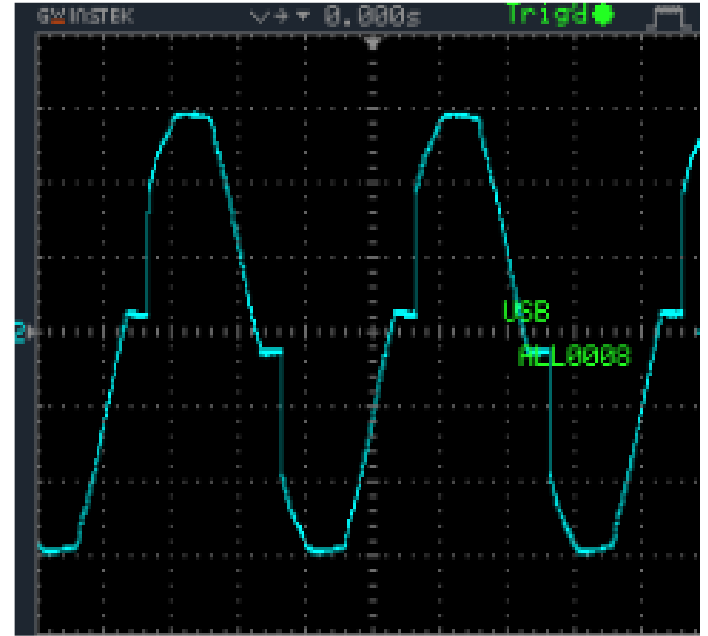

Gambar 12. Hasil pengukuran pada filter rangkaian Zero Crossing Detector

Pada hasil pengujian rangkaian didapatkan hasil tegangan input dan output relative sama. Pengujian dilakukan sebanyak 10x secara realtime, dimulai dari 10 menit hingga 720 menit, hasil yang didapatkan antara input dan output sama. Kelebihan pada rangkaian ini adalah adanya filter untuk noise yang dihasilkan oleh tegangan PLN, sehingga power supply mendapatkan tegangan $A C$ yang lebih bersih. Penggunaan triac dan optocopler terbukti efekti untuk menghaluskan gelombang yang masih memiliki noise.

Rangkaian kapasitif pada alat berfungsi optimal untuk menyaring gelombang yang memiliki frekuensi yang tidak stabil.

Dari hasil yang didapatkan saat proses pengujian, ada beberapa hal yang menjadi point yaitu penggunaan komponen yang tepat akan berdampak pada hasil keluaran ZCD, hasil ini sejalan dengan hasil penelitian yang dilakukan (Wall \& Member, 2012) dimana dikatakan bahwa noise yang terdapat pada tegangan sangat mempengaruhi dari alat/beban yang kita gunakan. Rangkan ZCD ini meminimalisir kesalahan dan noise yang terdapat pada sumber input.

\section{SIMPULAN DAN SARAN}

Kesimpulan yang dapat dihasilkan pada penelitian ini adalah rancang bangun rangkaian pengaman zero crossing detector dapat terealisasi dengan menggunakan beberapa literatur sebagai pustaka, penggunaan komponen elektronika sebagai inti dari rangkaian yang akan dibangun. Setelah merlukan riset terkait rangkaian pengaman Zero Crossing Detector didapatkan simpulan bahwa rangkaian Zero Crossing Detector berfungsi dengan baik sebagai pengaman tegangan dari jala-jala PLN. Pengujian alat ini dilakukan di laboratorium komputer dan dipasangkan langsung pada beban yaitu komputer. Jangka waktu pengujian kurang lebih sampai 8 jam, pengujian ini dilakukan untuk melihat dan pengukur seberapa tangguh alat ini mampu bekerja dan mengamankan power supplay komputer, adapun rangkaian penting pada alat Zero Crossing Detector ini yaitu Penggunaan rangkaian dioda IN4007 sebagai filter awal tegangan jala-jala PLN, rangkaian kapasitif terbukti mampu memfilter noise dari tegangan jala-jala PLN. Rangkaian Triac dan Optocopler berfungsi menstabilkan tegangan dan sebagai pengaman untuk power supply, sehingga tegangan yang masuk ke power supply menjadi lebih stabil dan jika terjadi tegangan berlebih masuk ke komputer maka alat Zero Crossing Detector ini akan lebih terdahulu short/hubung singkat, sehingga power supply komputer akan menjadi lebih aman dan dapat memperpanjang masa hidup dari power supply komputer tersebut.

Adapun saran yang bisa diberikan untuk pengembangan hasil penelitian ini adalah pada rangkaian Zero Crossing Detector bisa dikembangkan pada penggunaan komponen yang lebih baik lagi dalam hal karakteristik komponen, mengingat beberapa komponen yang ada dipasaran kualitasnya masih belum optimal. Pengembangan pada rangkaian pengaman yaitu rangkaian Optocoppler agar lebih di diperhatikan saat terjadi beban berlebih agar bisa langsung short, sehingga power supply tidak terbakar.

Kedepannya perlu dikembangkan untuk penstabil frekuensi, sehingga frekuensi yang penggangu dapat dapat difilter. Perlu dikembangkan dalam bentuk digital dan penggabungan mikrokontroler dalam rangkaian Zero Crossing Detector.

\section{UCAPAN TERIMAKASIH}


Penulis mengucapkan banyak terima kasih untuk terselesaikannnya penelitian ini beserta laporannya. Ucapan terima kasih penulis tujukkan kepada STIKI Indonesia sebagai instansi dan tempat penelitian, kepada kepala lembaga pengembangan inovasi dan kreativitas STIKI untuk bantuan dan ijin untuk menggunakan peralatan dalam rangka menguji hasil penelitian, kepada kepala lembaga penelitian dan pengabdian masyarakat untuk periode pengajuan proposal penelitian PPDS pada tahun 2017 dengan no kontrak penelitian 05/06/LPPM/VI/2017. Terima kasih juga ditujukkan kepada teman-teman kolega yang sudah membantu dalam sumbang pikiran, dan kepada mahasiswa STIKI yang sudah berkenan membantu serta keluarga yang sudah mendukung penelitian ini.

\section{DAFTAR RUJUKAN}

Agus, S. (2017). Rancang Bangun Pengendali Motor 1 Fasa Dengan Metode Zero Crossing Detector Berbasis Arduino. Universitas Muhammadiyah Surakarta.

Dasar, E. (2012). Zero Crossing Detector. Retrieved from http://elektronikadasar.web.id/zero-crossing-detector/

Dedy, R. (2001). Mengenal Elektronika. Jakarta: Erlangga.

Erwanda, R. (2016). Rancang Bangun Prototipe Pengendali Kecepatan Motor.

Fields, I. R. K., Paul, R., City, P., Barrie, R., \& Ng, P. (1994). United States Patent [191.

Gupta, A., Thakur, R., \& Murarka, S. (2013). An Efficient Approach to Zero Crossing Detection Based On, 3(5), 834-838.

Kustija, J. (2014). Elektronika Industri. Bandung: Universitas Pendidikan Indonesia.

Wall, R. W., \& Member, S. (2012). Simple Methods for Detecting Zero Crossing, 3-7.
Yeole, V., Dhurve, S., Sure, S., Meshram, A., Meshram, A., \& Engineering, E. (2017). Design of Single Phase Automatic Power Factor Controller Using Microcontroller. International Research Journal of Engineering and Technology(IRJET), 4(3), 1809-1813. Retrieved from https://irjet.net /archives/ V4/i3/IRJET-V4I3415.pdf 